\title{
PEMBELAAN HAK MANGSA KEMALANGAN JALAN RAYA BERASASKAN INSURANS DAN DIAT
}

\section{The Defence of Road Traffic Accident Victims' Rights According to Insurance and Diyah}

\author{
Siti Aisyah Samudin ${ }^{1}$ \\ Siti Zubaidah Ismail ${ }^{2}$
}

\begin{abstract}
Claims for damages of road traffic accidents in Malaysia are usually made through procedures in court. This occurs when there is a dispute over the liability and quantum of damages that should be paid by the guilty party. In the absence of a dispute, an out-of-court settlement may be exercised. The court process however, should not necessarily be done in Islamic compensation system called diyah. Diyah allows both parties to settle down their claim of damages with the presence of aqilah. If the accused has committed negligence that causes injury or death to the victims, it is obligatory to pay a number of compensation to victim or their heirs. Therefore, the objective of this research is to examine the rights of the victims involved in road traffic accident
\end{abstract}

\footnotetext{
PhD Candidate, Department of Shariah and Law, Academy of Islamic Studies, University of Malaya, 50603 Kuala Lumpur, aisy_awani@siswa.um.edu.my

2 Associate Professor, Department of Shariah and Law, Academy of Islamic Studies, University of Malaya, 50603 Kuala Lumpur, szubaida@um.edu.my
} 
both through the civil law system and the Islamic compensation system (diyah). An overview of road accident laws in Malaysia has been discussed in this paper including the Civil Law Act 1956 (Act 67), the Road Transport Act 1987 (Act 333), and the Insurance Act 1996 (Act 533). Rights and responsibilities arising from accidents also have been discussed. Using bibliographical studies, observation and semi structured interview as a methods of collecting data, the research finding indicates that victims are not being under a proper defence of their right. The victims have to go through the long process in order to get the quantum awarded by the court or insurance company. Hence, this research proposed compensation system based on diyah. Legal reform is necessary to address this issue.

Keywords: claims, damages, insurance, diyah, road traffic accident

\section{PENDAHULUAN}

Umum mengetahui bahawa setiap pemilik kenderaan diwajibkan untuk memiliki polisi insurans seperti yang diperuntukkan oleh Akta Pengangkutan Jalan 1987. ${ }^{3}$ Pemilikan ke atas polisi insurans ini bertujuan untuk melindungi ahlinya daripada sebarang kerugian sebagaimana sebelum kemalangan jalan raya berlaku. Tuntutan ganti rugi bagi kes kemalangan jalan raya di Malaysia pada kebiasaannya dibuat melalui prosedur di dalam mahkamah. Hal ini berlaku apabila wujudnya pertikaian berkenaan liabiliti dan takat ganti rugi yang sepatutnya dibayar oleh pihak yang bersalah. Sekiranya tidak wujud pertikaian, maka penyelesaian luar mahkamah boleh dilaksanakan. Hal sebaliknya berlaku dalam sistem diat. Kaedah pembayaran melalui diat membenarkan proses keadilan dibuat oleh mangsa dan 'aqilah pihak pesalah dalam mensabitkan bayaran. Sekiranya pihak tertuduh sabit melakukan kecuaian sehingga menimbulkan kecederaan atau kematian, maka 'aqilahnya wajib untuk membayar diat ke atas mangsa atau waris mangsa. Justeru, kupasan mendalam berkenaan undang-undang kemalangan jalan raya di

\footnotetext{
Akta Pengangkutan Jalan 1987 (Akta 333) berfungsi menetapkan kawalan kenderaan bermotor dan lalu-lintas di jalan raya di Malaysia dan menguatkuasakan bahawa insurans motor adalah wajib. Seksyen 90(1) Akta Pengangkutan Jalan 1987 menyatakan bahawa: 'adalah menjadi kesalahan bagi mana-mana individu yang menggunakan atau menyebabkan atau membenarkan individu lain untuk menggunakan kenderaan motor melainkan suatu polisi insurans itu berkuatkuasa atau lain-lain bentuk perlindungan berkaitan dengan risiko pihak ketiga'.
} 
Malaysia disertakan dalam penulisan ini. Hak dan tanggungjawab berbangkit daripada kemalangan turut dibincangkan.

\section{INSURANS KENDERAAN DALAM PERUNTUKAN UNDANG- UNDANG DI MALAYSIA}

Prosedur tuntutan pampasan pada dasarnya merujuk kepada undang-undang bertulis di Malaysia. Undang-undang tersebut adalah Akta Undang-undang Sivil 1956 (Akta 67), Akta Pengangkutan Jalan 1987 (Akta 333), Akta Perkhidmatan Kewangan 2013 (Akta 758), dan Akta Perkhidmatan Kewangan Islam 2013 (Akta 759).

\section{Akta Pengangkutan Jalan 1987 (Akta 333)}

Akta Pengangkutan Jalan 1987; selepas ini disebut Akta 333 merupakan sumber perundangan yang dirujuk bagi mentafsirkan dan menentukan istilah kemalangan, kenderaan dan jalan raya. Tafsiran bagi istilah-istilah ini pula signifikan bagi membezakan kemalangan jalan raya dengan kemalangan di jalan persendirian seterusnya membolehkan penentuan liabiliti dikenakan. Akta ini merupakan sumber perundangan utama di Malaysia yang memperuntukkan pembelaan kepada mangsa kemalangan jalan raya.

Akta ini berfungsi menetapkan kawalan kenderaan bermotor dan lalulintas di jalan raya di Malaysia dan menguatkuasakan bahawa insurans motor adalah wajib. Seksyen 90(1) Akta Pengangkutan Jalan 1987 menyatakan bahawa menjadi kesalahan bagi mana-mana individu yang menggunakan atau menyebabkan atau membenarkan individu lain untuk menggunakan kenderaan motor melainkan suatu polisi insurans itu berkuatkuasa atau lain-lain bentuk perlindungan berkaitan dengan risiko pihak ketiga.

Seterusnya, melalui seksyen 96, syarikat insurans diwajibkan menjelaskan ganti rugi kepada mangsa selepas penghakiman diputuskan. Akta ini juga memperuntukkan berkenaan kecuaian dan kesalahan kesalahan yang mengakibatkan kemalangan jalan raya beserta hukuman serta perlindungan pihak ketiga terhadap risiko yang berbangkit daripada penggunaan kenderaan bermotor.

\section{Akta Undang-undang Sivil 1956 (Akta 67)}

Akta Undang-undang Sivil 1956; selepas ini disebut sebagai Akta 67 merupakan statut perundangan utama yang dirujuk dalam menentukan 
kuantum ganti rugi bagi mangsa kemalangan jalan raya. Akta ini pertama kali digubal pada tahun 1956 dengan merujuk undang-undang komon dan kaedah-kaedah ekuiti yang ditadbirkan di England. Seksyen 7 Akta 67 ada memperuntukkan perincian berkenaan pampasan kepada keluarga seseorang khusus kerana kehilangan yang disebabkan oleh kematiannya. ${ }^{4}$ Sebaliknya perincian berkenan kecederaan peribadi pula diperuntukkan di dalam Seksyen 28A selepas berlakunya pindaan pada tahun 1984.

Pada tahun 1984 pindaan baru telah dibuat untuk memasukkan seksyen 28A atas ganti rugi berkenaan dengan kecederaan diri. Pindaan ini membawa perubahan kepada undang-undang dengan meletakkan kaedah pengiraan dan penilaian ganti rugi jika orang yang cedera hidup dan menderita akibat kejadian itu. Lantaran itu, beberapa elemen kerugian diperuntukkan disertakan dengan kaedah tetap bagi pengiraan kuantum ganti rugi bagi kehilangan pendapatan masa hadapan dan kehilangan penyaraan. ${ }^{5}$

Walau bagaimanapun, kaedah pengiraan ini juga mengundang tafsiran berbeza kepada mahkamah sekaligus tidak menyelesaikan masalah jurang perbezaan dan kepelbagaian kadar ganti rugi yang diputuskan. Hal ini dapat dilihat dalam kes Perumal a/l Sendra Yakaundra v. Kalasom Arshad \& Anor ${ }^{6}$ dan Nurul Jannah Johari v. Chan Kam Seng \& Anor. ${ }^{7}$ Kedua-dua kes ini merupakan kes kecederaan di bahagian tempurung kepala akibat kemalangan jalan raya. Walau bagaimanapun, mahkamah telah menetapkan pampasan sebanyak RM10,000 bagi kes Perumal dan RM5,000 bagi kes Nurul Jannah untuk kecederaan yang sama.

Seksyen 7(3) turut menambah peruntukan baru yang menyatakan bahawa jumlah yang akan diawardkan sebagai ganti rugi bagi suatu tindakan kerana kesedihan adalah sepuluh ribu ringgit. ${ }^{8}$ Namun demikian, suatu tuntutan bagi ganti rugi kerana kesedihan hendaklah hanya untuk faedah suami atau isteri si mati. Sebaliknya, jika si mati belum dewasa dan tidak berkahwin maka ganti rugi kesedihan ini adalah untuk ibu bapanya sahaja. ${ }^{9}$

Seksyen 28A Akta 67 merupakan peruntukan yang memberi perincian berkenaan ganti rugi bagi kecederaan diri. Gantirugi kesakitan dan penderitaan

$4 \quad$ Seksyen 7, Akta Undang-undang Sivil 1956. Kemalangan-Kemaangan Maut dan Keberterusan Kausa-Kausa Tindakan.

5 Seksyen 28A, Akta Undang-undang Sivil 1956 Pindaan 1984.

6 Perumal a/l Sendra Yakaundra v. Kalasom Arshad \& Anor [2008] PIR [22].

7 Nurul Jannah Johari v. Chan Kam Seng \& Anor [2008] 1 PIR [15]

8 Seksyen 7(3A) namun tertakluk kepada subseksyen (3D) Akta Pengangkutan Jalan 1987.

$9 \quad$ Seksyen (3B)(a) dan (b). 
yang disebabkan oleh kecederaan pula perlu mengambil kira mengambil kira akan kesedaran bahawa jangka hidupnya akan atau mungkin akan berkurang. Bagi ganti rugi kehilangan mata pencarian pada masa hadapan pula, mahkamah perlu mengambil kirabahawa plaintif jika bukan kerana kecederaan yang berlaku, sememangnya akan hidup sihat dan aktif serta menggunakan tenaganya sendiri untuk mencari pendapatan. ${ }^{10}$ Plaintif yang berumur 55 tahun dan ke atas pada masa kecederaan berlaku adalah tidak layak memohon ganti rugi ini. ${ }^{11}$

Selain itu, kaedah tetap pengiraan kuantum ganti rugi bagi kehilangan pendapatan dan kehilangan pendapatan pada masa hadapan ini juga perlu mengambilkira had umur mangsa. Sekiranya mangsa pada masa kematian atau kecederaan telah mencapai umur 55 tahun dan ke atas, ganti rugi bagi elemen ini tidak layak diperoleh. ${ }^{12}$ Had umur 55 tahun perlu diberi penilaian semula dan disesuaikan dengan status ekonomi negara hari ini memandangkan had umur persaraan minimum juga telah dipinda kepada 60 tahun. ${ }^{13}$ Malahan, terdapat beberapa sektor pekerjaan dan industri swasta yang mewajarkan pekerjanya untuk berkhidmat sehingga mencapai umur 70 tahun. ${ }^{14}$ Oleh sebab itu, jika pindaan umur tidak dilakukan, kebajikan pihak mangsa akan terabai berikutan hilangnya punca pendapatan yang sepatutnya dimiliki dalam tempoh kemalangan sehingga tarikh persaraan.

\section{Akta Perkhidmatan Kewangan 2013 (Akta 758)}

Akta Perkhidmatan Kewangan 2013 (Akta 758) merupakan suatu Akta untuk mengadakan peruntukan bagi pengawalseliaan dan penyeliaan institusi kewangan, sistem pembayaran dan entiti berkaitan yang lain dan pengawasan pasaran wang dan pasaran pertukaran asing untuk menggalakkan kestabilan kewangan dan bagi perkara yang berhubungan, berbangkit atau bersampingan dengannya. Hal ini termasuk perihal pembayaran gantirugi kepada mangsamangsa kemalangan yang memiliki polisi insurans yang sah.

Akta 758 mentafsirkan "polisi kemalangan diri" ertinya polisi yang memperuntukkan faedah kewangan tetap atau faedah yang bersifat tanggung rugi, atau kedua-duanya, terhadap risiko mengalami kecederaan atau kematian

\footnotetext{
$10 \quad$ Seksyen $28 \mathrm{~A}(2)(\mathrm{ci})$

11 Seksyen $28 \mathrm{~A}(2)$ (ci)

12 Seksyen 7(3)(iv)(a) dan Akta 28A(2)(c)(i) Akta Undang-undang Sivil 1956

13 Seksyen 4 Akta Umur Persaraan Minimum Minimum 2012 (Akta 753)

14 Kamal Halili Hassan, 'Akta Umur Persaraan Minimum 2012 (Akta 753); Ulasan Perundangan’, Jurnal KANUN, 2 (2014): 298.
} 
orang yang diinsuranskan akibat suatu kemalangan atau menjadi tidak upaya akibat daripada penyakit. Jadual 10 akta yang sama menyatakan peruntukan bagi pembayaran wang polisi apabila kematian pemunya polisi di bawah polisi hayat, termasuk suatu polisi hayat di bawah seksyen 23 Akta Undang-Undang Sivil 1956 [Akta 67], dan suatu polisi kemalangan diri, yang diambilnya atas hayatnya sendiri.

Jadual 10 menghuraikan pembahagian wang polisi dalam penjalanan pentadbiran yang emnyentuh perihal antirugi bagi kemalangan. Perkara 12(1) jadual ini memperuntukkan suatu tuntutan atau sebahagian daripada suatu tuntutan yang dibuat di bawah polisi hayat, atau di bawah polisi kemalangan diri atas kematian pemunya polisi tidak dibayar oleh penanggung insurans berlesen dalam tempoh enam puluh hari dari tarikh pemberitahuan tuntutan itu, penanggung insurans itu hendaklah membayar faedah kompaun minimum pada kadar purata deposit tetap yang terpakai bagi tempoh dua belas bulan untuk bank berlesen yang disiarkan oleh Bank ditambah satu peratus atau apa-apa kadar lain sebagaimana yang ditentukan oleh Bank, atas jumlah wang polisi selepas tamatnya tempoh enam puluh hari sehingga tarikh pembayaran. ${ }^{15}$

Walau bagaimanapun, sekiranya baki wang polisi kena dibayar oleh penanggung insurans berlesen kepada wasi atau pentadbir yang sah bagi harta pusaka pemunya polisi yang mati di bawah subsubperenggan 8(2)(b), faedah yang kena dibayar di bawah subperenggan (1) hendaklah hanya terpakai atas baki wang polisi apabila tamat tempoh enam puluh hari dari masa wasi atau pentadbir yang sah mengemukakan perintah probet atau surat kuasa mentadbir atau perintah pembahagian sehingga tarikh pembayaran. ${ }^{16}$

\section{Akta Perkhidmatan Kewangan Islam 2013 (Akta 759)}

Akta Perkhidmatan Kewangan Islam 2013 (Akta 759) suatu Akta untuk mengadakan peruntukan bagi pengawalseliaan dan penyeliaan institusi kewangan Islam, sistem pembayaran dan entiti berkaitan yang lain dan pengawasan pasaran wang Islam dan pasaran pertukaran asing Islam untuk menggalakkan kestabilan kewangan dan pematuhan Shariah dan bagi perkara yang berhubungan, berbangkit atau bersampingan dengannya. Akta 759 mentafsirkan "sijil takaful kemalangan diri" sebagai sijil takaful yang memperuntukkan manfaat kewangan tetap atau manfaat yang bersifat tanggung rugi, atau kedua-duanya, terhadap risiko mengalami kecederaan atau kematian orang yang dilindungi akibat suatu kemalangan atau menjadi tidak upaya akibat daripada penyakit. Pembayaran manfaat sijil takaful kemalangan

\footnotetext{
15 Jadual 10 12(1) Akta Perkhidmatan Kewangan Islam 2013

16 Seksyen 12(2) Akta Perkhidmatan Kewangan Islam 2013
} 
diri dinyatakan dalam Jadual 10 yang memperuntukkan pembayaran manfaat takaful apabila kematian peserta takaful di bawah sijil takaful keluarga dan sijil takaful kemalangan diri, yang dikeluarkan berkenaan dengan suatu kontrak takaful yang dibuat oleh peserta takaful atas hayatnya. ${ }^{17}$

Dalam Jadual ini, suatu sebutan mengenai sijil takaful adalah sebutan mengenai sijil takaful keluarga dan suatu sijil takaful kemalangan diri yang diambil oleh peserta takaful atas hayatnya dirinya yang memperuntukkan bagi pembayaran manfaat takaful atas kematiannya. Perkara 12(1) memperuntukkan jika suatu tuntutan atau sebahagian daripada suatu tuntutan yang dibuat di bawah sijil takaful keluarga, atau di bawah sijil takaful kemalangan diri atas kematian peserta takaful tidak dibayar oleh pengendali takaful berlesen dalam tempoh enam puluh hari dari tarikh pemberitahuan tuntutan itu, pengendali takaful berlesen itu hendaklah membayar gantirugi minimum pada kadar pulangan pelaburan kumpulan wang risiko peserta ditambah satu peratus atau apa-apa kadar lain sebagaimana yang ditentukan oleh Bank, atas jumlah manfaat takaful selepas tamatnya tempoh enam puluh hari sehinga tarikh pembayaran, yang mana satu peratus itu kena dibayar daripada kumpulan wang pemegang saham.

Perkara 12(2) pula menghendaki gantirugi yang kena dibayar di bawah subperenggan (1) hendaklah hanya terpakai atas baki manfaat takaful sekiranya baki manfaat takaful kena dibayar oleh pengendali takaful berlesen kepada wasi atau pentadbir yang sah bagi harta pusaka peserta takaful yang mati di bawah subperenggan 8(3). Hal ini apabila tamat tempoh enam puluh hari dari masa wasi atau pentadbir yang sah mengemukakan perintah probet atau surat kuasa mentadbir atau perintah pembahagian sehingga tarikh pembayaran.

\section{ORGANISASI PENGELOLA INSURANS DAN TAKAFUL DI MALAYSIA SERTA PERSATUAN-PERSATUAN BERKAITAN}

\section{Bank Negara Malaysia}

Di Malaysia, Bank Negara Malaysia (BNM) telah diberi tanggungjawab bagi menyelia dan mengawal industri insurans dan takaful. Bank Negara Malaysia merupakan badan berkanun yang mula beroperasi pada 26 Januari 1959. ${ }^{18}$ Bank Negara Malaysia tertakluk kepada Akta Bank Negara Malaysia 2009

17 Jadual 10, Akta 759.

18 Mohd. Sadad Mahmud \& Radiah Abd. Kader, 'Perkembangan Takaful di Malaysia: Satu Kajian Undang-Undang Kewangan Islam,' KANUN: Jurnal Undang-Undang Malaysia, 24/2 (2012): 246. 
yang berperanan dalam menggalakkan kestabilan monetari dan kewangan bagi menyediakan persekitaran yang kondusif untuk pertumbuhan ekonomi Malaysia yang mapan. ${ }^{19}$

Cadangan pelaksanaan sistem pampasan melalui kaedah diat turut meletakkan BNM sebagai satu institusi penting yang mengawal selia pampasan melalui pengawalan syarikat insurans serta persatuan-persatuan insurans di bawahnya. Ganti rugi yang bersifat tetap sebagaimana yang terdapat dalam sistem diat memberi kepastian dan memudahkan pembayaran pampasan oleh pengendali takaful dan syarikat insurans kepada mangsa kemalangan. Lantas, bagi memastikan kemampanan syarikat insurans/takaful dalam memenuhi tuntutan pemegang polisi bertanggungjawab menetapkan keperluankeperluan/garis panduan kewangan yang berhemat yang perlu dipenuhi oleh syarikat insurans/takaful bagi memastikan tahap kecukupan modal sepadan dengan profil risiko pada setiap masa. Keperluan-keperluan/garis panduan ini akan dikaji dari masa ke semasa bagi memastikan ianya kekal relevan dalam persekitaran yang berubah-ubah. ${ }^{20}$

Pada asalnya, industri insurans dikawal selia oleh Kementerian Kewangan sehinggalah BNM mengambil alih tugasan tersebut pada 1 Mei 1988. Bagi tujuan ini, BNM telah menubuhkan dua jabatan khas bagi melicinkan pentadbirannya, iaitu Jabatan Pengawalan Insurans dan Jabatan Penyeliaan Insurans. Objektif utama Jabatan Pengawalan Insurans ditubuhkan adalah bagi mengurus, mentadbir, dan menguatkuasakan Akta Insurans 1996 (kini tertakluk kepada Akta 758) serta mengeluar dan melaksana garis panduan dan dasar dalam industry tersebut. Sebaliknya, Jabatan Penyeliaan Insurans pula bertanggungjawab dalam menyelia dan memantau keadaan kewangan syarikat-syarikat insurans, takaful, serta pengendali syarikat insurans atau takaful semula (reinsurer). ${ }^{21}$

Seterusnya, Akta Insurans 1996 menghendaki sesebuah organisasi yang berminat untuk menjalankan urusniaga insurans hendaklah menjadi ahli kepada mana-mana persatuan bergantung kepada jenis perniagaan mereka sama ada broker insurans, urusniaga insurans hayat atau insurans am. Persatuanpersatuan ini semestinya dipantau oleh BNM dengan dokumen perlembagaan (constituent document) yang wajib mendapat kelulusan daripada BNM

19 Bank Negara Malaysia, 'Kestabilan Kewangan: Penyeliaan', laman sesawang Bank Negara Malaysia, http://www.bnm.gov.my/index.php?ch=fs\&pg=fs spv\&ac=395\&lang=bm, dicapai pada 21 Julai 2017.

20 Afiza Abdullah (Jabatan Pembangunan Insurans, Bank Negara Malaysia), dalam temu bual beliau dengan penulis, pada 3 Mei 2018).

21 Nor Azila Zainal Abidin, Kerjaya dalam Bidang Insuran (Batu Caves: PTS Publishing House, 2008), 32. 
terlebih dahulu. ${ }^{22}$ Antara persatuan insurans yang ditubuhkan di Malaysia adalah Persatuan Insurans Am Malaysia (PIAM), Life Insurance Association of Malaysia (LIAM), Insurance Broker Association of Malaysia (IBAM), Association of Malaysian Loss Adjusters (AMLA), dan National Insurance Association of Malaysia (NIAM).

Syarat yang serupa turut dikenakan ke atas syarikat-syarikat takaful Malaysia. Akta takaful 1984 menghendaki sebarang perniagaan takaful perlulah dilesenkan terlebih dahulu di bawah BNM. Begitu juga halnya dengan broker dan pelaras kerugian takaful yang disyaratkan agar memiliki lessen di bawah BNM serta turut serta dalam persatuan-persatuan takaful bergantung kepada jenis urusniaga takaful yang diceburi. ${ }^{23}$ Antara persatuan yang menaungi syarikat urusniaga takaful adalah Association of Malaysian Loss Adjusters (AMLA) dan Malaysian Insurance and takaful Brokers Association (MITBA). ${ }^{24}$

\section{Persatuan-Persatuan yang Meanungi Industri Insurans dan Takaful Malaysia}

\section{a) Persatuan Insurans Am Malaysia (PIAM)}

Persatuan Insurans Am Malaysia (PIAM) ditubuhkan pada Mei 1979 sebagai mematuhi Akta Pertubuhan, 1966 (Disemak 1987). PIAM merupakan persatuan statutori yang diiktiraf oleh Kerajaan Malaysia untuk semua penanggung insurans berdaftar yang menjalankan perniagaan insurans di negara ini. PIAM berperanan dalam membantu BNM bagi mewujudkan industri insurans yang am yang stabil dan kukuh. PIAM juga berperanan dalam mewakili dan menjaga kepentingan ahlinya dalam industri insurans am selagi tidak bercanggah dengan mana-mana peruntukan undang-undang dan peraturan sedia ada. PIAM juga bertanggungjawab dalam memberi nasihat dan memberi bantuan kepada ahlinya apabila patut dan perlu selain merapatkan jaringan sosial antara persatuan insurans lain dalam dan luar negara. PIAM juga bertanggungjawab bagi mengadakan perbincangan dengan BNM dalam proses menggubal sebarang undang-undang, peraturan, dan undang-undang

22 Bank Negara Malaysia, 'Kestabilan Kewangan: Penyeliaan', laman sesawang Bank Negara Malaysia, http://www.bnm.gov.my/index.php?ch=fs\&pg=fs spv\&ac=395\&lang=bm, dicapai pada 21 Julai 2017.

23 Bank Negara Malaysia, 'Kestabilan Kewangan: Penyeliaan.'

24 Bank Negara Malaysia, 'Kestabilan Kewangan: Penyeliaan.' 
kecil berkaitan insurans am. ${ }^{25}$ Syarikat-syarikat insurans yang menjadi anggota PIAM antaranya ialah AmGeneral Insurance, AIG Malaysia Insurance Berhad, dan Overseas Assurance Corporation (Malaysia) Berhad. ${ }^{26}$

\section{b) Life Insurance Association of Malaysia (LIAM)}

Pertubuhan LIAM dibentuk pada tahun 1974 yang didaftarkan di bawah Akta Pertubuhan 1966 sebagai sebuah persatuan perdagangan. Keahlian LIAM adalah mandatori sebagaimana yang dikehendaki peruntukan dalam Akta Insurans $1996 .{ }^{27}$ Sehingga Julai 2017, LIAM direkodkan mempunyai 16 ahli, di mana 14 adalah syarikat insurans hayat dan 2 syarikat reinsurans hayat. Objektif LIAM adalah untuk mempromosikan industri insurans hayat progresif, meningkatkan pemahaman dan penghargaan awam untuk insurans hayat serta menaik taraf imej dan profesionalisme industri insurans hayat serta menyokong pihak berkuasa dalam pengawalseliaan sektor ekonomi Malaysia. Syarikat-syarikat insurans yang menjadi anggota LIAM antaranya ialah Allianz Life Insurance Malaysia Berhad, AmMetLife Insurance Berhad dan Etiqa Insurance Berhad. ${ }^{28}$

\section{c) Association of Malaysian Loss Adjusters (AMLA)}

AMLA merupakan badan persatuan perdagangan yang menaungi majoriti syarikat ajuster berdaftar di Malaysia. Pada masa ini AMLA mempunyai 36 syarikat yang menjadia anggota. Menyentuh berkenaan syarikat yang menjalankan urusniaga penyelarasan kerugian (ajuster), tiada rekod atau fakta sahih yang mengesahkan fasa profesion ajuster bermula di Malaysia. Namun dipercayai, syarikat ajuster insurans pertama telah ditubuhkan sejak tahun 1930-an lagi. Beberapa firma yang ada pada masa itu pada dasarnya terlibat dalam tuntutan marin. Tuntutan insurans kelas lain pula diuruskan oleh syarikat insurans tersebut secara bersendirian. ${ }^{29}$

25 Persatuan Insurans Am Malaysia, 'About Us', laman sesawang PIAM, http:// www.piam.org.my/about-us/, dicapai pada 23 Julai 2017.

26 Persatuan Insurans Am Malaysia, 'Company Member', laman sesawang PIAM, http://www.piam.org.my/about-us/member-companies/, dicapai pada 23 Julai 2017.

27 Nor Azila Zainal Abidin, Kerjaya dalam Bidang Insuran, 33.

28 Life Insurans Association Malaysia, 'About LIAM, Vission \& Mission', laman sesawang LIAM, https://www.liam.org.my/index.php/home/liam-missionavision, dicapai pada 23 Julai 2017.

29 Association of Malaysian Loss Adjuster, 'About AMLA', laman sesawang AMLA, http://www.amla1981.org/?page_id=1777, dicapai pada 23 julai 2017. 
Di Malaysia, syarikat ajuster yang membabitkan kebakaran, motor dan kerugian umum telah berakar pada tahun 1950-an. Pembentukan AMLA telah dicatatkan dalam tempoh ini dan didaftarkan sebagai sebuah persatuan di bawah Akta Persatuan 1966 pada tahun 1981 bagi mewakili ahli-ahlinya dalam hal-hal yang mempengaruhi kepentingan mereka dalam industri insurans. ${ }^{30}$

AMLA berperanan dalam memantau dan mengawal anggotanya untuk mematuhi semua perkara perundangan dan Peraturan Persatuan serta mematuhi peruntukan semua undang-undang di Malaysia, khususnya Akta Perkhidmatan Kewangan 2013 dan Akta Perkhidmatan Kewangan Islam 2013. Perkhidmatan yang disediakan oleh ahli kami termasuk tuntutan berkaitan motor dan bukan motor. Peranan adjuster dalam tuntutan motor adalah untuk menyiasat keadaan kerugian dengan tujuan menentukan sama ada kerugian itu berada dalam liputan polisi dan dengan beberapa pihak yang diwakilkan, berunding dan bersetuju dengan kesimpulan tuntutan insurans bagi pihak syarikat insurans. ${ }^{31}$

Sebahagian besar daripada kerja penyesuaian di mana anggota AMLA terlibat berkaitan dengan pemeriksaan dan penilaian kenderaan yang rosak akibat perlanggaran, dan juga penyiasatan terhadap kecurian kenderaan dan liabiliti berkaitan kemalangan jalan raya. Syarikat-syarikat insurans yang menjadi anggota AMLA antaranya ialah Aman Insurance Adjusters \& Investigators Sdn. Bhd, Associated Adjusters Sdn. Bhd, dan Alfa Adjusters (M) Sdn. Bhd. ${ }^{32}$

\section{d) Malaysian Insurance and Takaful Brokers Association (MITBA)}

Persatuan Broker Insurans dan Takaful Malaysia (MITBA) merupakan satusatunya badan kebangsaan Insurans dan Takaful yang telah berdaftar dengan Pendaftar Pertubuhan pada 3 Disember $1974 .{ }^{33}$ MITBA berperanan dalam memberi nasihat kepada ahli, pengawal selia, pengguna, persatuan perdagangan dan pihak berkepentingan lain mengenai isu-isu insurans utama. MITBA juga menyediakan latihan, nasihat teknikal, bimbingan mengenai peraturan dan sokongan perniagaan. Peranan MITBA adalah untuk meningkatkan status

\footnotetext{
30 Association of Malaysian Loss Adjuster, 'About AMLA'.

31 Association of Malaysian Loss Adjuster, 'Role of Adjuster', laman sesawang AMLA, http://www.amla1981.org/?page_id=3041, dicapai pada 23 Julai 2017.

32 Association of Malaysian Loss Adjuster, 'Member Companies', laman sesawang AMLA, http://www.amla1981.org/?page_id=3045, dicapai pada 23 Julai 2017.

33 The Malaysian Insurance and Takaful Brokers Association, 'History of Mitba', laman sesawang MITBA, http://www.mitba.org.my/About-MITBA/History-ofMITBA, dicapai pada 23 Julai 2017.
} 
broker insurans dan takaful menerusi pembangunan profesional dan dengan mewujudkan piawai kelayakan dan amalan etika yang lebih baik. ${ }^{34}$

Ahli MITBA merangkul standard kelakuan, profesionalisme, dan amalan yang ketat. Ini memastikan bahawa mereka mengekalkan piawaian etika tertinggi dan keyakinan yang sangat baik, asas perniagaan insurans, dalam semua kegiatan yang mereka lakukan. Jawatankuasa Eksekutif MITBA, terdiri daripada sembilan (9) wakil rakyat yang dipilih setiap 2 tahun semasa AGM dari keanggotaannya, bermesyuarat setiap bulan untuk memberi arahan dan idea. Sekretariat MITBA menyediakan pentadbiran dan sokongan sehari ke hari ke Persatuan. Syarikat-syarikat insurans yang menjadi anggota MITBA antaranya ialah Alloy Insurance Brokers Sdn Bhd, Anika Insurance Brokers Sdn Bhd dan Antah Insurance Brokers Sdn Bhd. ${ }^{35}$

\section{Biro Insurans Motor (Motor Insurers' Bureau - MIB)}

Biro Insurer Motor (Motor Insurers' Bureau - MIB) bukanlah sebuah syarikat yang menjalankan urusniaga insurans. Sebaliknya, badan ini merupakan tabung bagi tujuan dana kenderaan bermotor. ${ }^{36}$ Biro ini ditubuhkan berdasarkan Perjanjian Utama pada 15 Januari 1968 dengan Menteri Pengangkutan dan penanggung insurans am yang dibenarkan. Biro ini menyediakan bayaran pampasan kepada mangsa-mangsa atau pihak ketiga kemalangan jalan raya dalam kes mangsa tersebut dinafikan hak menerima ganti rugi. Situasi ini boleh berlaku disebabkan ketiadaan insurans atau insurans yang berkuatkuasa, seperti yang dikehendaki di bawah seksyen 90 Akta Pengangkutan Jalan 1987. ${ }^{37}$

Di bawah perjanjian tersebut, apabila penghakiman yang diperolehi di mahkamah (di Malaysia Barat) tidak dilaksanakan dalam tempoh 28 hari, maka MIB bertanggungjawab untuk membayar jumlah penghakiman penuh bagi pihak orang yang tidak diinsuranskan atas kematian atau kecederaan kepada pihak ketiga. Oleh sebab MIB adalah sebuah syarikat berhad dengan jaminan, ia tidak memegang apa-apa aset untuk melindungi liabilitinya, tetapi

34 The Malaysian Insurance and Takaful Brokers Association, 'About MITBA', laman sesawang MITBA, http://www.mitba.org.my/About-MITBA/Our-Vision,Mission-Objectives, dicapai pada 23 Julai 2017.

35 The Malaysian Insurance and Takaful Brokers Association, 'About MITBA'.

36 Abdullah Ahmad (Peguam Berdaftar Berpengalaman Mengendali Kes Tuntutan Kemalangan Jalan Raya), dalam temu bual beliau dengan penulis, pada 23 Oktober 2016.

37 The Malaysian Insurance Institute, Pre-Contract Examination Insurance Agent (Shah Alam: The Malaysian Insurance Institute, 2014), 130. 
ahli-ahlinya yang merupakan syarikat insurans am menjamin pembayaran liabiliti apabila timbul keperluan. ${ }^{38}$

Walau bagaimanapun, selepas 1 Januari 1992, perjanjian utama telah dibatalkan dan digantikan dengan Gantian Perjanjian Utama yang memasukkan keanggotaan Sabah dan Sarawak. Perjanjian gantian ini memperuntukkan sekadar bayaran ihsan atau elaun sahaja kepada mangsa kemalangan motor yang disebabkan oleh pemandu yang tidak diinsuranskan, tanpa perlu mendapatkan penghakiman mahkamah. Pemandu yang tidak diinsuranskan adalah orang yang tidak mempunyai insurans yang sah atau polisi insurans telah tamat tempoh. Walaupun tidak ada peruntukan khusus untuk mangsa pemandu tidak dapat dikesan atau kes langgar lari, MIB akan membuat bayaran ihsan mengikut budi bicara mutlaknya kepada mangsa kemalangan atau tanggungannya, untuk kecederaan atau kematian yang disebabkan oleh penggunaan kenderaan bermotor di jalan awam. ${ }^{39}$

Selain itu, dalam usaha untuk membuat tuntutan ke atas pihak insurans, terdapat kemungkinan berlakunya pertikaian berkenaan tuntutan yang dibuat. Pertikaian antara pihak yang menuntut dan insurer mungkin melibatkan salah satu daripada dua isu berikut, iaitu; i) melibatkan liabiliti atau tanggungjawab, (sama ada insurer boleh dipertanggungjawabkan atau tidak) dan ii) jika insurer bertanggungjawab, berapakah amaun atau jumlah tuntutan penyelesaian. Lainlain pertikaian mungkin timbul disebabkan oleh kelewatan menyelesaikan tuntutan, fakta bertulis tidak didedahkan dan pertikaian melibatkan dokumentasi.

Pertikaian yang timbul boleh diselesaikan melalui beberapa saluran perundingan dan perbincangan kedua-dua pihak. Penyelesaian melalui timbangtara juga boleh dilakukan bagi menyelesaikan amaun atau jumlah tuntutan yang dibincangkan dalam suasana yang kurang formal berbanding dengan penyelesaian mahkamah dan diadili oleh penimbang tara. Perantaraan juga merupakan alternatif penyelesaian pertikaian, iaitu melalui Biro Perantaraan Kewangan (FMB), sebuah badan bebas yang ditubuhkan untuk mengadili pertikaian tuntutan.

Keputusan yang dibuat oleh FMB akan mengikat dan perlu dipatuhi oleh insurer, tetapi ia tidak mengikat insured atau pihak yang menuntut. Langkah terakhir adalah melalui prosedur undang-undang. Sekiranya perundingan dan perantaraan gagal mencapai keputusan atau jalan penyelesaian, insured

38 The Malaysian Insurance Institute, Pre-Contract Examination Insurance Agent, 130.

39 The Malaysian Insurance Institute, Pre-Contract Examination Insurance Agent, 131. 
berhak untuk mengambil tindakan undang-undang melalui proses mahkamah. Walau bagaimanapun, kaedah ini bukan sahaja memakan belanja yang tinggi tetapiia juga memakan masa yang lama. ${ }^{40}$ Selain itu, syarikat insurans juga adalah terikat dengan Garis Panduan Amalan Penyelesaian Tuntutan yang memperuntukkan tempoh masa yang ditetapkan untuk insurer menyelesaikan satu tuntutan.

Jadual 1: Proses Tuntutan dan Tempoh Masa Penyelesaian

\begin{tabular}{|c|c|}
\hline Perkara & Tempoh Masa \\
\hline $\begin{array}{l}\text { Akuan penerimaan notis } \\
\text { pemberitahuan }\end{array}$ & 7 hari selepas tarikh didaftarkan \\
\hline $\begin{array}{l}\text { Menyerahkan tugas kepada ajuster: } \\
\text { - Bandar besar } \\
\text { - lokasi lain - } 14 \text { hari }\end{array}$ & $\begin{array}{l}7 \text { hari } \\
14 \text { hari }\end{array}$ \\
\hline Ajuster menghantar laporan & 7 hari \\
\hline Kelulusan dari insurer & 7 hari \\
\hline Bayaran tuntutan & $\begin{array}{l}7 \text { hari - bayaran balik tuntutan } \\
14 \text { hari - tuntutan di bawah RM } 1 \\
\text { juta } \\
21 \text { hari - tuntutan melebihi RM } 1 \\
\text { juta }\end{array}$ \\
\hline Penolakan tuntutan & 14 hari \\
\hline
\end{tabular}

Sumber: The Malaysian Insurance Institute

\section{KEMALANGAN JALAN RAYA DI BAWAH SKOP PERUNDANGAN ISLAM}

Kupasan berkenaan kemalangan jalan raya di bawah skop Syariah Islam tidak dibincangkan secara mendalam dalam kitab-kitab fiqh klasik. Kemalangan di bincangkan secara umum yang dimasukkan di bawah aspek jarimah atau jināyah merangkumi kesalahan yang tidak disengajakan atau tersalah (al-khata'). ${ }^{41}$ Terma al-khata' boleh dimaksudkan dalam aspek kecuaian.

\footnotetext{
40 The Malaysian Insurance Institute, Pre-Contract Examination Insurance Agent, 134.

41 'Abd al-Qādir 'Awdah, al-Tashri' al-Jinā' '̀ al-Islāmi Muqāranan bi al-Qānūn alWaḍ' 'ì, vol. 1 (Bayrūt: Dār al-Kutub al-Azali, 2008), 67.
} 
Perbincangan berkenaan aspek al-khata' dalam kitab fiqh klasik adalah berbentuk umum merangkumi kecederaan dan kematian kerana berburu, kecuaian sendiri mahupun di jalan awam.

Biarpun kupasan khusus berkenaan kemalangan jalan raya masih disusun di dalam kitab fiqh klasik, namun bukan bermakna perbincangan tersebut tidak ada. Hal ini kerana, pengetahuan para fuqaha' silam belum sampai kepada era teknologi kini. Aspek perbincangan dan ijtihad mereka terhadap isu kemalangan jalan raya adalah terhad ke atas mod pengangkutan yang ada pada zaman mereka, iaitu terdiri daripada haiwan, perkapalan dan kenderaan berteknologi mudah dan ringkas. ${ }^{42}$

Perbincangan berkenaan kemalangan jalan raya di mulai dengan kupasan berkenaan hak-hak di jalan raya serta ganti rugi (al-daman) berkaitan kerosakan atau gangguan kepada hak individu. ${ }^{43}$ Asasnya, suatu kecederaan dan kematian yang disebabkan oleh kecuaian maka satu jaminan berbentuk pampasan perlu dikeluarkan oleh pihak yang bersalah kepada mangsa, iaitu melalui kaedah diat.

Para sarjana fiqh kontemporari turut meletakkan perbincangan berkenaan kemalangan jalan raya di bawah aspek maqāṣid al-sharī'ah, iaitu dalam aspek memelihara nyawa yang menjadi tujuan kedua dalam lima maqāșid yang utama. ${ }^{44}$ Rangka bagi mewujudkan satu sistem pampasan bagi mangsa kemalangan jalan raya yang komprehensif adalah perlu untuk memberikan hak kepda pihak mangsa. Pelaksanaannya pula terletak di bawah kuasa pemerintah, iaitu khalifah (pengganti) kepada pemerintahan Nabi SAW yang bertindak mengawal keselamatan dan siasah dunia berpandukan kepada Syariah. ${ }^{45}$

Berbeza dengan tuntutan pampasan di bawah sivil yang diletakkan di bawah tort kecuaian, kemalangan jalan raya di bawah perundangan Islam diletakkan dalam lingkungan jenayah membunuh dan mencederakan. Pihak yang bersalah diwajibkan membayar pampasan nyawa kepada atau warisnya

42 Abdul Basir Mohamad, 'Tanggungjawab Pemunya dan Pemilik Haiwan dalam Undang-Undang Tort Islam,’ Jurnal Islamiyyat, 20 (1999): 3-19.

43 Wahbah al-Zuhaylī, Nazariyyah al-Daman wa Ahkām al-Mas'ūliyyah alMadaniyyah wa al-Jinā 'iyyah fì al-Fiqh al-Islāmī Dirāsah Muqāranah (Dimashq: Dār al-Fikr, 1998), 235.

44 Mohd Saad Abdul Rahman, 'Kemalangan Jalan Raya Tanggungjawab Siapa?' laman sesawang IKIM, http://www.ikim.gov.my/index.php/en/artikel/7360kemalangan-jalan-raya-tanggungjawab-siapa, dicapai 19 Oktober 2016.

45 Al-Mawardī, Ab̄̄ al-Ḥassan 'Alī Ibn Muḥammad, al-Aḥkām as-Sulțāniyyah wa al-Wilāyah al-Dīniyyah (Kuwait: Maktabah Dār Ibn Qutaybah, 1989), 45. 
jika terbukti pihak bersalah adalah tidak sengaja dan cuai. ${ }^{46}$ Kes kecuaian sebegini pada kebiasaannya berhubungkait dengan pengabaian peraturan jalan raya seperi memandu melebihi had laju yang dibenarkan atau memandu di dalam keadaan mabuk. ${ }^{47}$

Menyentuh berkenaan peraturan jalan raya, hak-hak di jalan raya yang dikupas di dalam perbincangan fiqh klasik seperti larangan melalui jalan orang lain tanpa izin, larangan menggali lubang di jalan awam dan sebagainya telah diperluaskan dalam perbincangan fiqh kontemporari. Peraturan jalan raya yang ditetapkan oleh pemerintah melalui badan-badan berwajib negara merupakan satu pendekatan mașālih al-mursalah. ${ }^{48}$

Dalam kes seperti ini kerajaan mempunyai hak untuk menggubal peraturan tertentu mengenai perkara-perkara ini, untuk kepentingan orang awam dan mewajibkan jika keadaan memerlukannya. Sebagai contoh, seseorang boleh berjalan di atas kedua-dua belah pihak, kanan dan kiri. Tidak ada arahan yang jelas dalam Syariah yang menyatakan arah mana seseorang itu perlu mendahului ketika memandu. Oleh itu, kerajaan mempunyai hak untuk menandakan arah tertentu atau laluan ketika memandu di jalan raya. ${ }^{49}$

Merujuk kepada hukuman bagipelaku cuai yang mengakibatkan kemalangan jalan raya, kedua-dua sarjana fiqh klasik dan kontemporari bersetuju bahawa pembayaran pampasan melalui diat merupakan kaedah terbaik. Pelaku cuai perlu membayar diat ke atas mangsa sebagaimana jumlah yang telah diletakkan di dalam nas, mahupun pendekatan ijtihad yang digunapakai oleh pemerintah. Kaedah diat akan memastikan pihak mangsa mendapat ganti rugi dalam apa jua keadaan kerana adanya unsur 'aqilah yang menyokong dana pelaku cuai tersebut. $^{50}$

Hukuman penjara pula tidak termasuk dalam konsep diat. Ia merupakan satu bentuk takzir yang dilaksanakan pemerintah sebagai hukuman tambahan. ${ }^{51}$

46 Mohd Saad Abdul Rahman, 'Kemalangan Jalan Raya Tanggungjawab Siapa?'

47 Seksyen 40 Akta Pengangkutan Jalan 1987.

48 Khalid Saifullah Al Rahmani, 'Fiqh of Traffic-Walking and Driving', laman sesawang Islamic Foundation of Toronto, http://www.islamicfoundation.ca/ general.aspx/answers/fiqh_of_traffic_-_walking_and_driving, dicapai pada 19 Oktober 2016.

49 Khalid Saifullah Al Rahmani, 'Fiqh of Traffic-Walking and Driving'.

50 Ahmad Muhammad Husni, 'The Status of Insurance as an Alternative to Aqilah for Diat Payments Pertaining to Road Accidents', International Business Management, 7/1 (2013): 8-13.

51 Ahmad Muhammad Husni, 'The Status of Insurance as an Alternative to Aqilah 
Diat tidak mewajibkan hukuman penjara kerana prinsip asasnya ialah indemniti, iaitu berusaha meletakkan pihak mangsa dalam posisi seperti mana sewaktu kemalangan tidak berlaku. Hukuman bagi pemandu cuai yang menyebabkan kematian boleh dikenakan diyah ringan, iaitu membayar kepada mangsa atau warisnya sebanyak 100 ekor unta atau yang senilai dengannya.

Dalam aspek lain, hukuman penjara tidak memberi apa-apa kesan fizikal yang positif ke atas mangsa melainkan rasa sedikit puas hati melihatkan pihak yang salah dipenjarakan. Namun, dari sudut pihak yang bersalah pula, hukuman penjara memang memberi pengajaran ke atas mereka namun dalam aspek lain turut mempengaruhi tanggungan mereka. Hal ini merupakan antara hikmah mengapa hukuman penjara tidak wajib disekalikan dengan diat.

Di Arab Saudi, undang-undang jenayah Syariah dan amalannya memperuntukkan pampasan nyawa bagi kesalahan tidak sengaja sebanyak RS, iaitu nilai harga bagi 100 ekor unta menurut jenisnya. ${ }^{52}$ Di Pakistan pula, pemandu yang memandu dengan cuai sehingga menyebabkan kematian atau kecederaan boleh dihukum dengan diat dan ditambah dengan takzir yang boleh membawa kepada hukuman penjara sehingga 10 tahun. ${ }^{53}$ Undang-undang ini dilaksanakan bersandar kepada nas al-Quran dan matan Hadis berkenaan diat yang telah diringkaskan oleh sarjana-sarjana fiqh klasik dan kontemporari berkenaan kemalangan jalan raya dalam skop perundangan Islam.

\section{'AQILAH DAN TAFSIRAN KONTEMPORARI}

Dalam sistem diat, pihak yang diwajibkan membayar diat ke atas mangsa dinamakan 'aqilah. 'Aqilah mengikut tafsiran ulama' silam merupakan pihak yang saling membantu dalam melangsaikan bayaran pampasan atas kecederaan yang dilakukan waris mereka. Pada zaman Rasulullah SAW dan sahabat, 'aqilah boleh terdiri daripada ahli-ahli qabilah, waris-waris mahupun ahli Diwan. ${ }^{54}$ Pihak yang wajib membayar diat dalam kalangan 'aqilah juga turut ditetapkan. Bagi jenayah pembunuhan, pembayar diat terdiri pada kerabat yang merdeka, baligh dan berkemampuan. Oleh itu, kanak-kanak, orang tidak siuman dan wanita tidak termasuk dalam kelompok 'aqilah. Walau bagaimanapun, Ibn Abidin berpandangan bahawa mereka termasuk dalam

for Diat Payments Pertaining to Road Accidents,' 9.

52 Mohd Saad Abdul Rahman, 'Kemalangan Jalan Raya Tanggungjawab Siapa?'

53 Mohd Saad Abdul Rahman, 'Kemalangan Jalan Raya Tanggungjawab Siapa?'

54 Ahmad Muhammad Husni, 'Kedudukan Insurans Sebagai Pengganti Aqilah Bagi Pembayaran Diat dalam Kes Kemalangan Jalan Raya Menurut Undang-undang Islam', International Journal of West Asian Studies, 4/1 (2012): 6. 
kelompok yang membayar diat jika mereka menjadi Ahli Diwan dan mereka juga melakukan jenayah pembunuhan. ${ }^{55}$

Muhammad Husaini dalam artikelnya mengulas berkenaan kaedah pembayaran diat berdasarkan fuqaha mazhab Hanafi dan Maliki. Beliau menerangkan bahawa pembunuh yang melakukan jenayah juga termasuk daripada golongan yang wajib membayar diat bersama-sama dengan 'aqilah. Pandangan ini disokong oleh laporan dari Umar yang berkata kepada Salamah Ibn Nu'aym yang telah membunuh seorang Islam yang disangkanya orang bukan Islam: "Ke atas kamu dan kaum kamu diat." Manakala menurut mazhab Shafie dan Hanbali, pembunuh diampunkan daripada membayar diat. ${ }^{56}$

Ahli akademik Islam kontemporari dan fuqaha' terdahulu seperti Ahmad Muhammad Husni, ${ }^{57}$ Siti Zubaidah Ismail, ${ }^{58}$ al-Zuhayli, ${ }^{59}$ al-Mawardī, ${ }^{60}$ dan al-Kasani $^{61}$ turut membincangkan berkenaan pembayaran kaffarah bagi kesalahan melibatkan jalan raya. Ibn Baz menyatakan bahawa sekiranya pemandu melanggar peraturan jalan raya seperti tidur ketika memandu, tidak mempunyai lesen memandu, berhenti di tempat yang dilarang atau lemah penglihatan sehingga menyebabkan kematian, maka diwajibkan kafarah dan diat dibayar oleh 'aqilahnya. ${ }^{62}$ Sebaliknya, jika pemandu cuai terhadap

55 Ahmad Muhammad Husni, 'Kedudukan Insurans Sebagai Pengganti Aqilah Bagi Pembayaran Diat dalam Kes Kemalangan Jalan Raya Menurut Undang-undang Islam', 5.

56 Ahmad Muhammad Husni, 'Kedudukan Insurans Sebagai Pengganti Aqilah Bagi Pembayaran Diat dalam Kes Kemalangan Jalan Raya Menurut Undang-undang Islam', 5 .

57 Ahmad Muhammad Husni, 'Kedudukan Insurans Sebagai Pengganti Aqilah Bagi Pembayaran Diat dalam Kes Kemalangan Jalan Raya Menurut Undang-undang Islam', 6.

58 Siti Zubaidah Ismail, 'Kecuaian dan Penentuan Liabiliti dalam Kes Kemalangan Jalan Raya Menurut Undang-undang Islam', Malaysian Journal of Syariah and Law, 1 (2009): 91.

59 Wahbah al-Zuhaylī, Naẓariyyah al-Daman wa Ahkām al-Mas'ūliyyah alMadaniyyah wa al-Jinā 'iyyah fì al-Fiqh al-Islāmī Dirāsah Muqāranah (Dimashq: Dār al-Fikr, 1998), 235.

60 Al-Mawardī, 'Alī Ibn Muhammad, al-Ḥāwī al-Kabīr fì Fiqh Madhhāb al-Imām al-Shāfi ‘̄: Wa huwa Sharh Mukhtassar al-Muzanī (Bayrūt: Dār al-Kutub al'Ilmiyyah, 1999), 375.

${ }^{61}$ Al-Kasānī, 'Ala al-Dīn, Baḍ̄' 'i ' al-Ṣanā'i ' fì Tartīb al-Sharā'i', vol. 7 (Bayrūt: Dār al-Kitāb al-'Arabī, 1982), 272.

62 Ahmad Muhammad Husni, 'Kedudukan Insurans Sebagai Pengganti Aqilah Bagi Pembayaran Diat dalam Kes Kemalangan Jalan Raya Menurut Undang-undang Islam', 5. 
kenderaannya seperti tidak menggantikan peralatan yang perlu diganti sehingga menyebabkan kematian, dia wajib melakukan kafarah dan diat dibayar oleh 'aqilahnya. ${ }^{63}$

Jika kemalangan berpunca dari beberapa orang pemandu, mereka semua perlu melakukan kafarah dan diat dibayar oleh 'aqilah masing-masing berdasarkan kepada kesalahan yang dilakukan oleh setiap pemandu. Manakala, kemalangan yang disebabkan oleh tindakan pemandu yang bertujuan untuk mengelakkan kemalangan seperti mengelak lubang besar di tengah jalan sehingga terbabas, maka pemandu tidak dikenakan kafarah dan 'aqilahnya tidak perlu membayar apa-apa diat. Jika mangsa kemalangan adalah seorang yang menyebabkan kemalangan tersebut seperti pemandu yang melanggar kereta yang sedang berhenti di lampu isyarat sehingga menyebabkan kematian dirinya sendiri maka gantian kerosakan perlu diambil dari hartanya dan diat kematian orang lain yang terlibat dalam kemalangan tersebut dibayar oleh 'aqilahnya.

Selain itu, jika pemandu tidak melanggar peraturan jalan raya dan tidak cuai dalam menjaga kenderaannya seperti kemalangan yang disebabkan tayar yang masih baik pecah atau disebabkan kegagalan peralatan yang menyebabkan kenderaan tidak boleh dikawal, maka dia tidak dikenakan kafarah dan diat. Mengikut kaedah asal, pemandu yang menyebabkan kemalangan jalan raya sehingga berlaku kematian, wajib melakukan kafarah dan diat perlu dibayar oleh 'aqilahnya walaupun dia tidak sengaja menyebabkan kemalangan tersebut kerana Allah telah mewajibkan diat kepada pembunuhan yang tidak disengajakan. ${ }^{64}$

Meneliti kepada sistem hidup masyarakat kini, didapati bahawa badan yang dinamakan 'aqilah sudah tidak wujud lagi. Ketiadaan elemen qabilah serta wujudnya ikatan kekeluargaan yang semakin longgar melemahkan aspek kebersamaan sebagai satu keluargga dan pasukan menyebabkan sistem 'aqilah sebagaimana yang wujud pada zaman Nabi SAW dan sahabat seperti hilang fungsinya. Namun demikian, terdapat nafas baru yang diberikan ke atas tafsiran 'aqilah dengan melihat kepada kemiripan fungsinya dengan sistem moden, iaitu insurans. Kebersamaan prinsip antara 'aqilah dan insurans yang berpegang atas dasar saling menjamin dan membantu melahirkan tafsiran

63 Ahmad Muhammad Husni, 'Kedudukan Insurans Sebagai Pengganti Aqilah Bagi Pembayaran Diat dalam Kes Kemalangan Jalan Raya Menurut Undang-undang Islam', 5.

64 Ahmad Muhammad Husni, 'Kedudukan Insurans Sebagai Pengganti Aqilah Bagi Pembayaran Diat dalam Kes Kemalangan Jalan Raya Menurut Undang-undang Islam', 5. 
'aqilah moden, iaitu dengan menyatakan bahawa insurans adalah bentuk sistem 'aqilah kontemporari.

Pada zaman kini, 'aqilah boleh ditafsirkan sebagai badan insurans yang bertanggungjawab mengeluarkan wang caruman pemegang polisinya untuk membayar ganti rugi kecederaan atau kematian akibat kemalangan jalan raya. Tafsiran ini berlaku kerana wujudnya persamaan dari sudut peranan dan sebab penubuhan kedua-dua badan ini, iaitu untuk saling membantu dan menjamin bagi sebarang risiko kerugian. Dalam usaha mencari dan meneliti titik integrasi antara diat dan insurans, didapati insurans motor adalah yang paling sesuai untuk diharmonisasikan dengan sistem diat. Dalam hal ini, insurans motor adalah termasuk dalam insurans am. Selains insurans motor, insurans am lain termasuklah insurans harta, marin, liabiliti, kemalangan pelbagai dan kejuruteraan.

Dari sudut pembayaran, prinsip dalam kaedah diat boleh digunapakai. Satu anggota tunggal diberikan bayaran penuh. Bagi anggota berpasangan, kehilangan satu anggotanya diberikan bayaran separuh. Prinsip ini diambil bersandarkan kepada hadis Nabi SAW berkenaan diat anggota. (Sunan Abi Daud, no. Hadis: 4564). Bayaran penuh boleh dirujuk melalui laporan-laporan perubatan serta laporan bagi kes-kes kecederaan peribadi yang telah diterbitkan. Nasihat daripada pakar perubatan juga adalah penting untuk diambil kira bagi menetapkan bayaran pampasan setiap anggota tubuh badan. Hal ini kerana wujudnya istilah-istilah baru bagi anggota dan kecederaan yang dialami yang tidak terdapat dalam istilah fiqh klasik. Seandainya prinsip bagi kuantum ganti rugi dapat ditetapkan dengan komprehensif, maka pelaksanaan kepada kes tuntutan pampasan bagi kemalangan jalan raya mampu diselesaikan dengan segera melalui perantaraan luar mahkamah.

\section{TUNTUTAN INSURANS OLEH MANGSA KEMALANGAN JALAN RAYA}

Polisi insurans motor/sijil takaful (secara kolektif dirujuk sebagai "polisi motor") menyediakan perlindungan kewangan kepada pemegang polisinya apabila kenderaan terlibat dalam kemalangan jalan raya. Walau bagaimanapun, terdapat had kepada tahap perlindungan kewangan yang disediakan. Oleh sebab itu, penting bagi setiap pemegang polisi untuk memahami skop perlindungan bagi setiap jenis polisi motor yang dicarum. ${ }^{65}$

65 Yuzvovich, Larisa, Elena Knyazeva, Elena Razumovskaya \& Vadim Katochikov, 'Vehicle Insurance Financial Mechanism,' Review of European Studies, 7/3 (2015): 99. 
Semasa membuat tuntutan motor yang melibatkan kecederaan diri, kematian, atau kerosakan harta benda pihak ketiga, tuntutan insurans boleh dibuat oleh mangsa atau wakilnya secara terus dengan penanggung insurans pihak lain yang terlibat atau melantik peguam untuk bertindak bagi pihak mangsa pada bila-bila masa. Sekiranya mangsa memilih untuk membuat tuntutan secara terus dengan penanggung insurans pihak lain yang terlibat, perlulah dipastikan bahawa pampasan yang akan diterima daripada penanggung insurans adalah mencukupi. ${ }^{66}$

Sikap berjaga-jaga dan wujudnya nasihat pakar adalah amat penting dalam mencapai sebarang penyelesaian berhubung pampasan dengan penanggung insurans pihak lain yang terlibat memandangkan penyelesaian tersebut adalah muktamad. Sebaliknya, jika pihak mangsa berpendapat bahawa pampasan yang ditawarkan kepada anda tidak mencukupi, rundingan boleh dibuat secara terus dengan penanggung insurans pihak lain yang terlibat atau atau mendapatkan nasihat guaman. Sekiranya tiada persetujuan dapat dibuat, maka pihak-pihak boleh meneruskan tuntutan melalui proses mahkamah. ${ }^{67}$

Dalam proses mendapatkan tuntutan insurans, beberapa dokumen penting melibatkan pihak-pihak serta maklumat kenderaan terlibat adalah diperlukan. Oleh sebab itu, adalah mustahak bagi pihak penuntut untuk mencatatkan seberapa banyak maklumat bagi melancarkan proses tuntutan seterusnya. Catatan tersebut termasuklah berkenaan butiran peribadi pemandu yang terlibat dalam kemalangan jalan raya seperti nama, nombor kad pengenalan, alamat, nombor lesen memandu dan nombor telefon, nama penanggung insurans kenderaan lain, buatan, model dan nombor pendaftaran kenderaan lain yang terlibat dalam kemalangan jalan raya, nombor pendaftaran trak tunda (jika ada). ${ }^{68}$

Pihak yang terlibat juga dinasihatkan untuk melakar gambar rajah ringkas kejadian kemalangan bagi memudahkan mereka untuk membuat laporan polis. Hal ini kerana undang-undang mewajibkan laporan polis dibuat dalam tempoh 24 jam selepas kemalangan berlaku. Pihak penuntut dikehendaki menghubungi terus pihak penanggung insurans sendiri atau merujuk kepada

66 Muhammad Zaim Azfar Jalaludin (Peguam Berdaftar Berpengalaman Mengendali Kes Tuntutan Kemalangan Jalan Raya), dalam temu bual beliau dengan penulis, pada 3 Ogos 2016.

67 Muhammad Zaim Azfar Jalaludin (Peguam Berdaftar Berpengalaman Mengendali Kes Tuntutan Kemalangan Jalan Raya), dalam temu bual beliau dengan penulis, pada 3 Ogos 2016.

68 Roslan Ramlee (Pegawai Penyiasat Trafik, IPD Shah Alam), dalam temu bual beliau dengan penulis, pada 4 April 2017. 
Persatuan Insurans Am Malaysia (PIAM) atau Persatuan Takaful Malaysia (MTA) dalam tempoh 7 hari dari tarikh berlakunya kemalangan. ${ }^{69}$

Tuntutan pampasan bagi kecederaan pihak ketiga boleh dituntut oleh pihak mangsa yang akan dibayar oleh pihak lain yang terlibat, iaitu pemandu yang diinsuranskan oleh syarikat yang didapati telah menyebabkan kemalangan berkenaan. Walau bagaimanapun, sekiranya pihak yang menuntut sendiri didapati bertanggungjawab atas kemalangan tersebut, maka mereka tidak akan menerima apa-apa pampasan daripada penanggung insurans pihak lain yang terlibat. Dalam hal lain, sekiranya pihak penuntut didapati turut menyebabkan kemalangan itu, maka jumlah pampasan yang diterima mungkin akan berkurangan melihat kepada liabiliti yang ditanggung pihak-pihak. Perlu diingatkan bahawa terdapat beberapa faktor yang menyebabkan tuntutan ditolak secara menyeluruh, iaitu dalam keadaan apabila cukai jalan atau insurans telah tamat tempoh. ${ }^{70}$

\section{MODEL PELAKSANAAN INSURANS DAN TAKAFUL MOTOR BAGI TUNTUTAN KEMALANGAN JALAN RAYA}

Insurans adalah pemindahan risiko daripada seorang individu atau organisasi kepada syarikat insurans. Syarikat insurans akan menerima bayaran daripada pemegang polisi dalam bentuk premium dan sekiranya anda mengalami sebarang kerugian atau kerosakan, syarikat insurans akan membayar pampasan kepada anda. ${ }^{71}$ Sebaliknya, takaful pula merupakan pelan perlindungan berdasarkan prinsip Syariah. Dengan mencarum sejumlah wang ke dalam dana takaful dalam bentuk caruman penyertaan untuk kebajikan (tabarru), pemegang polisi akan memeterai kontrak (aqad) bagi membolehkan mereka menjadi seorang peserta dengan bersetuju untuk saling membantu antara satu sama lain, sekiranya salah seorang peserta mengalami kerugian yang ditetapkan. ${ }^{72}$

69 Roslan Ramlee (Pegawai Penyiasat Trafik, IPD Shah Alam), dalam temu bual beliau dengan penulis, pada 4 April 2017.

70 Persatuan Insurans Am Malaysia, Laporan Tahunan (Kuala Lumpur: PIAM, 2013).

71 Muhammad Yamin Ismail, 'Perbandingan Kontrak Insurans Islam dan Konvensional', Jurnal Penyelidikan Islam, 19 (2006): 57.

72 Azman Mohd Noor \& Mohamad Asmadi Abdullah, 'Takaful (Islamic Insurance) Benefit: Ownership and Distribution Issues in Malaysia', Journal of Islamic Economics, Banking and Finance, 5/3 (t.t.): 36. 
Konsep ini mengandungi prinsip kerjasama, saling membantu dan tanggungjawab bersama yang merupakan asas insurans secara Islam atau takaful. ${ }^{73}$ Prinsip indemniti pula penting dalam insurans dan takaful. Berdasarkan prinsip ini, perlindungan insurans akan membayar kerugian dengan meletakkan pihak yang berisiko pada keadaan yang sama sebelum mereka mengalami kerugian. ${ }^{74}$

Model pembayaran dan pelaksanaan premium bagi insurans dan takaful motor di Malaysia telah mengalami liberalisasi. Liberalisasi insurans motor bermaksud harga produk insurans motor tidak akan lagi ditentukan berdasarkan Tarif Motor (senarai harga yang telah ditetapkan). Sebaliknya, harga produk insurans motor akan ditentukan oleh setiap penanggung insurans dan pengendali takaful. Hal ini bermaksud, pengguna boleh menikmati pilihan produk insurans motor yang lebih luas pada harga yang kompetitif dengan membuat perbandingan kepada kepelbagaian produk insurans daripada syarikat insurans dan takaful. ${ }^{75}$

Fasa 1 Liberalisasi Tarif Motor dan Tarif Kebakaran telah diperkenalkan pada 1 Julai 2016. Semasa fasa permulaan ini, penanggung insurans dan pengendali takaful diberikan fleksibiliti untuk menawarkan produk baharu motor dan perlindungan tambahan yang tidak ditetapkan di bawah tarif yang sedia ada. Mulai 1 Julai 2017, liberalisasi kadar premium produk Motor Komprehensif; dan produk Motor Pihak Ketiga Kebakaran dan Kecurian telah mula dilaksanakan dan penetapan harga premium akan ditentukan oleh penanggung insurans dan pengendali takaful masing-masing. ${ }^{76} \mathrm{Hal}$ ini bermaksud, penanggung insurans dan pengendali takaful boleh mengenakan premium yang berpadanan dengan faktor risiko yang lebih luas yang sedia ada dalam kumpulan pemegang polisi yang diinsuranskan dan juga menjual produk-produk baharu yang tidak ditetapkan di bawah tarif. ${ }^{77}$

73 Joni Tamkin Borhan \& Che Zarrina Sa'ari, 'The Principle of al-Takaful (Collective Responsibility) in Islam and Its Practice in the Operations of Syarikat Takaful Malaysia Berhad', Jurnal Usuluddin, 17 (2003), 33-56.

74 Salleh Buang, Undang-undang Kecuaian di Malaysia, terj. Asiah Mohd Yusof, (Kuala Lumpur: Dewan Bahasa dan Pustaka, 1999), 328.

75 Bank Negara Malaysia, 'Liberalisation of Motor Insurance', laman sesawang Bank Negara Malaysia, http://www.bnm.gov.my/index.php?ch=en announcement\&pg=en_announcement\&ac=529, dicapai pada 03 Ogos 2017.

76 Bank Negara Malaysia, 'Liberalisation of Motor Insurance'.

77 Persatuan Insurans Am Malaysia, 'Liberalisasi Tarif Motor', laman sesawang PIAM, http://www.piam.org.my/phased-liberalisation-section/liberalisasi-tarifmotor-soalan-lazim/, dicapai pada 03 Ogos 2017. 
Sebelum konsep liberalisasi insurans motor diperkenalkan di Malaysia, model pembayaran premium insurans dan takaful dikira berdasarkan nilai diinsuranskan dan model kenderaan. Selain itu, penanggung insurans dibenarkan menggunakan bebanan premium terhad berdasarkan umur pemandu dan jumlah kemalangan yang pernah dialami. Bergantung pada rekod tuntutan oleh pemandu, premium yang dikira untuk dibayar diselaraskan dengan Diskaun Tanpa Tuntutan (No Claim Discount). Lazimnya, pemandu yang mempunyai rekod memandu yang baik akan menikmati peratusan NCD yang lebih tinggi sehingga $55 \% .^{78}$

Mulai 1 Julai 2017, dalam persekitaran yang liberal, lebih banyak faktor risiko akan diambil kira untuk menentukan premium. Selain nilai diinsuranskan, keupayaan enjin kenderaan, umur kenderaan dan umur pemandu, premium mungkin didorong oleh faktor lain. Faktor-faktor ini mungkin termasuk ciriciri keselamatan di dalam kenderaan, tempoh kenderaan itu berada di jalan raya, lokasi geografi kenderaan (dalam kawasan yang mengalami insiden kecurian yang tinggi) dan kesalahan lalu lintas yang pernah dialami. Faktorfaktor ini akan menentukan profil risiko kumpulan pemegang polisi yang akan menentukan pula kadar premium. Kadar premium pula boleh berbeza antara satu penanngung insurans dengan yang lain sementelah wujudnya perbezaan dalam menentukan profil risiko tersebut. ${ }^{79}$

\section{ASAS LIABILITI DAN PEMBUKTIAN BAGI KES KEMALANGAN JALAN RAYA}

\section{Liabiliti}

Dalam mana-mana tuntutan melibatkan kecederaan peribadi dan kematian bagi kes kemalangan jalan raya, antara soalan utama yang penting untuk dikemukakan ialah pihak manakah yang bertanggungan? Hal ini kerana, penentuan pihak yang bersalah sudah tentu dapat memastikan pihak yang berliabiliti bagi membayar pampasan kepada mangsa. Penentuan ini juga mempengaruhi kuantum ganti rugi yang akan ditetapkan sekiranya terdapatkan kecuaian sumbangan oleh pihak mangsa. Penyelesaian kes ini pula boleh

\footnotetext{
78 Bank Negara Malaysia, 'Liberalisation of Motor Insurance', laman sesawang Bank Negara Malaysia, http://www.bnm.gov.my/index.php?ch=en announcement\&pg=en_announcement\&ac=529, dicapai pada 03 Ogos 2017.

79 Persatuan Insurans Am Malaysia, 'Liberalisasi Tarif Motor', laman sesawang PIAM, http://www.piam.org.my/phased-liberalisation-section/liberalisasi-tarifmotor-soalan-lazim, dicapai pada 03 Ogos 2017.
} 
terlaksana melalui penyelesaian di luar Mahkamah mahupun melalui perintah Mahkamah bergantung kepada kerjasama dan persetujuan pihak-pihak. ${ }^{80}$

Siapakah pihak yang berhak untuk menentukan liabiliti tergantung kepada latar belakang sesuatu kes. Pada asasnya, sekiranya penyelesaian kes dijalankan di luar Mahkamah, pihak mangsa yang diwakili oleh peguamnya boleh mengharapkan peguam mereka untuk menyiasat kes itu. Pihak peguam akan mengumpul semua bukti merangkupi laporan polis, laporan perubatan, keterangan-keterangan bergambar serta dokumen lain yang berpotensi meletakkan liabiliti ke atas pihak yang cuai sebelum suatu liabiliti ditentukan dan dipersetujui pihak-pihak. ${ }^{81}$

Pihak yang berkemungkinan menanggung liabiliti bagi suatu tuntutan pada kebiasaannya memiliki liabiliti insurans. Risiko yang ditanggung oleh klien mereka akan dipindahkan kepada syarikat insurans. Seterusnya, pihak insurans akan menjalankan siasatan mereka sendiri seterusnya membuat keputusan liabiliti bebas. Dalam keadaan ini, pihak-pihak sudah memiliki penentuan liabiliti mereka masing-masing. Sekiranya pihak-pihak yang terlibat bersetuju dengan penetuan mereka, maka penyelesaian kes boleh diteruskan secara baik tanpa melibatkan prosiding mahkamah. Sebaliknya, jika persetujuan tidak mampu dicapai maka pihak mangsa boleh memfailkan tuntutan di mahkamah untuk memberi kuasa kepada Yang Arif Hakim menentukan pihak yang berliabiliti seterusnya menentukan kuantum ganti rugi. ${ }^{82}$

Proses penentuan liabiliti dari sudut perundangan Islam adalah berasaskan kepada kaedah fiqh al-bayyinah 'ala al-mudda' $\bar{l}$ wa al-yamin 'ala man ankara. ${ }^{83}$ Kaedah ini mengeluarkan prinsip bahawa pihak penuntut yang merupakan mangsa dikehendaki mengemukakan segala keterangan yang

80 Muhammad Zaim Azfar Jalaludin (Peguam Berdaftar Berpengalaman Mengendali Kes Tuntutan Kemalangan Jalan Raya), dalam temu bual beliau dengan penulis, pada 3 Ogos 2016.

81 Abdullah Ahmad (Peguam Berdaftar Berpengalaman Mengendali Kes Tuntutan Kemalangan Jalan Raya), dalam temu bual beliau dengan penulis, pada 23 Oktober 2016.

82 Abdullah Ahmad (Peguam Berdaftar Berpengalaman Mengendali Kes Tuntutan Kemalangan Jalan Raya), dalam temu bual beliau dengan penulis, pada 23 Oktober 2016.

83 Jalāl al-Dīn Abd Raḥmān al-Suyūṭ̄i, al-Ashbah wa al-Nazā' ir fì Qawā 'id wa Furū ‘ Fiqh al-Shāfi 'ì (Bayrūt: Dār al-Kutub al-'Ilmiyyah, 1983), 509; al-Bayḥaqī, Sunan al-Bayḥaqī al-Ṣughra, vol. 4 (Bayrūt: Dār al-Kutub al-'Ilmiyyah, 2008), 188, Kitāb al-Da'wa wa al-Bayyinat, "Bāb al-Bayyinah 'ala al-Mudda'ī wa al-Yamīn 'ala man Ankara", no. hadis 4329. 
membuktikan pihak Defendan adalah berliabiliti. Walaupun asas kaedah ini banyak digunakan di dalam kes-kes mal, namun dalam kes-kes jenayah ia turut digunapakai. Pihak yang menuntut perlu membuktikan adanya pencerobohan hak (al-i'tida') dan kerosakan (al-darar) bagi mensabitkan liabiliti ke atas pihak yang cuai. ${ }^{84}$

\section{Pembuktian}

Asas utama bagi membuktinya adanya kesalahan yang mebawa kepada penanggungan liabiliti adalah wujudnya kecuaian. Majoriti utama timbulnya tuntutan bagi kecederaan peribadi adalah terdapat satu pihak atau lebih yang bertindak cuai. Kecuaian pada dasarnya boleh berlaku apabila seseorang itu bertindak atau tidak melakukan kewajipan yang jatuh di bawah piawian penjagaan seseorang yang munasabah. Kecuaian juga boleh berlaku apabila suatu tindakan atau peninggalan menyebabkan kerosakan kepada orang lain. ${ }^{85}$

Bagi membuktikan adanya kecuaian yang membawa kepada penanggungan liabiliti, pihak yang tercedera perlu membuktikan wujudnya apa-apa kewajipan yang gagal dilakukan oleh pihak defendan kepada plaintif seperti keluar simpang secara melulu, tidak memberi lampu isyarat, tidak berjagajaga dengan keadaan sekeliling sehingga dengan cuai melanggar mangsa dan sebagainya. ${ }^{86}$ Pihak mangsa juga perlu membuktikan wujudnya perlanggaran undang-undang seperti memandu melebihi had laju yang dibenarkan, memandu sambil memandang telefon bimbit dan sebagainya. ${ }^{87}$

Pihak mangsa perlu membuktikan bahawa defendan adalah penyebab kepada kecederaan yang dialami mangsa. Pembuktian melalui kaedah ini pada kebiasaannya menjadi bukti yang cukup jelas bagi meletakkan defendan dalam posisi berliabiliti bagi kebanyakan kes kecederaan. ${ }^{88}$ Sebagai contoh dalam kes melibatkan perlanggaran kereta, kereta defendan yang benar-benar

84 Muhammad Ahmad Saraj, Daman al-Udwan fi al-Fiqh al-Islami Dirasah Fihiyyah Muqaranah bi Ahkam al-Masuliyyah al-Taqsiriyyah fi al-Qanun (al-Qāhirah: Dār al-Thaqafah li al-Nasyr wa al-Tawzi, 1990), 128.

85 David Goguen, J.D., 'Determining Fault in a Personal Injury Case,' laman sesawang AllLaw.com, http://www.alllaw.com/articles/nolo/personal-injury/ determining-fault.html, dicapai pada 19 Oktober 2016.

86 David Goguen, J.D., 'Determining Fault in a Personal Injury Case,'

87 David Goguen, J.D., 'Determining Fault in a Personal Injury Case,'

88 David Goguen, J.D., 'Determining Fault in a Personal Injury Case,' 
berada di belakang kereta mangsa sudah tentu menjadi penyebab yang jelas kepada punca berlakunya kemalangan dan tidak perlu dipersoalkan lagi. ${ }^{89}$

Plaintif juga perlu membuktikan adanya kerosakan dan kerugian yang timbul kesan daripda kemalangan seperti perbelanjaan perubatan, perbelanjaan bagi rawatan, kerosakan harta benda dan sebagainya. Kaedah pembuktian bagi menentukan liabiliti ini pada dasarnya adalah selari dengan perundangan Syariah. Para sarjana fiqh kontemporari mensyaratkan dua elemen utama yang perlu dibuktikan dalam menentukan liabiliti seseorang, iaitu wujudnya pencerobohan hak dan kerosakan..$^{90}$

Dalam dalam kes tuntutan melibatkan kecederaan peribadi, fakta dan dokumen perlu dibawa dan dibuktikan keesahannya oleh plaintif. Pihak defendan pula secara amalannya akan cuba menimbulkan sebarang keraguan berkenaan keesahan fakta dan dokumen yang didatangkan dihadapannya. Keraguan tersebut boleh timbul dari sudut fakta yang bercanggah, dokumen yang tidak benar atau wujudnya kecuaian sumbangan daripada pihak mangsa. ${ }^{91}$

Pihak defendan akan berusaha menimbulkan adanya kecuaian sumbangan bagi merendahkan peratusan gantirugi atau paling tidak meletakkan keduadua pihak pada kedudukan seimbang. Hal ini merupakan satu kaedah pertahanan untuk membela dirinya daripada sebarang liabiliti atau paling tidak meminimakan kuantum ganti rugi yang perlu dibayar. ${ }^{92}$

\footnotetext{
89 David Goguen, J.D., 'Determining Fault in a Personal Injury Case,'

90 Wahbah al-Zuhaylī, Nazariyyah al-Daman wa Aḥkām al-Mas'ūliyyah alMadaniyyah wa al-Jinā 'iyyah fì al-Fiqh al-Islāmī Dirāsah Muqāranah (Dimashq: Dār al-Fikr, 1998), 237.

91 David Goguen, J.D., 'Determining Fault in a Personal Injury Case,'

92 David Goguen, J.D., 'Determining Fault in a Personal Injury Case,'
} 
Rajah 1: Ringkasan Proses Pembuktian dan Penentuan Liabiliti

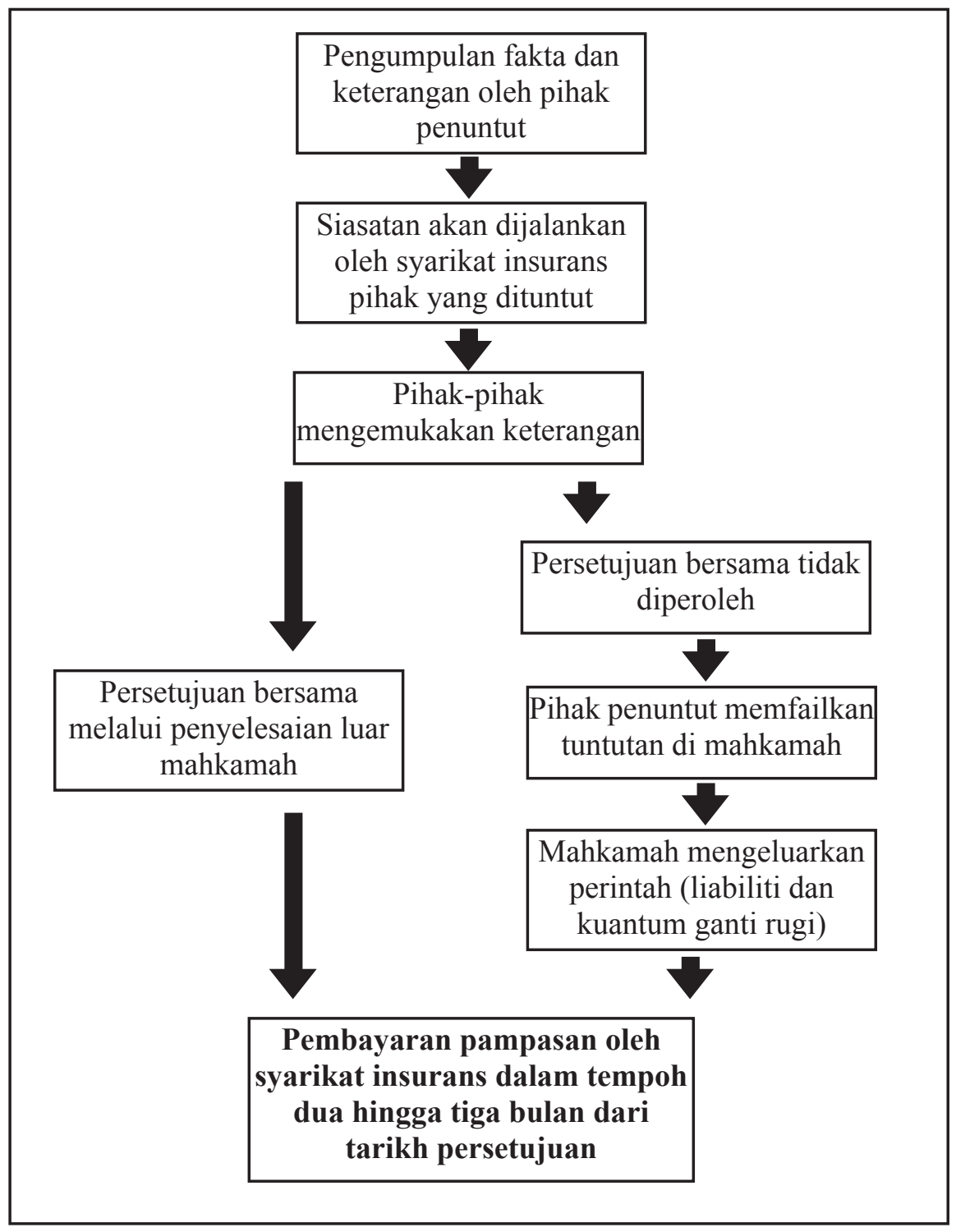




\section{Contoh Perbandingan Kadar Pampasan menurut Sivil dan Diat}

Haslifah Hashim dalam kajiannya mendapati bahawa kadar pampasan yang ditetapkan mahkamah atau pihak insurans adalah jauh lebih rendah berbanding kadar yang diperlukan oleh hayat manusia. ${ }^{93}$ Hal ini dibuktikan melalui beberapa kes terpilih sebagai contoh dalam kes Mohamed Mat Amin \& ORS v. Mohd Rabu Ihsan ${ }^{94}$ yang melibatkan mangsa kemalangan meninggal dunia, Hakim telah mnetapkan pampasan gantirugi sebanyak RM72,000 namun nilai sebenar setelah kaedah Faktor Nilai Hidup Manusia (HLVF) digunakan ialah sebanyak RM109,044. Pengiraan berdasarkan kaedah diat berdasarkan nilaian emas memperuntukkan pampasan yang besar daripada itu. Apatah lagi ia melibatkan kemalangan jiwa, diat yang diperuntukkan ialah diat penuh, iaitu bersamaan RM615,000. ${ }^{95}$ Begitu juga dalam kes Azman Kasri \& Anor v. Md. Isa Endut \& Government of Malaysia ${ }^{96}$ Mangsa dalam kes ini telah mengalami kecederaan parah dan perlu dipotong di bahagian kaki kiri (lutut ke bawah) yang mengakibat kecacatan kekal. Hakim memutuskan kadar pampasan bagi kecederaan yang dialami Plaintif ialah sebanyak RM171,480. ${ }^{97}$ Sebaliknya kaedah diat memperuntukkan kadar pampasan $1 / 2$ diat akibat kehilangan satu dari dua anggota, iaitu sebanyak RM307,500. Meneliti kepada perbezaan kadar pampasan ini, penulis berpandangan kaedah diat merupakan kaedah paling sesuai untuk dilaksanakan disebabkan penetapan nilai setiap anggota yang tinggi dan lebih mudah untuk dirujuk serta diikuti oleh mahkamah.

\section{PENUTUP}

Menurut amalan di Malaysia, hak membuat tuntutan sememangnya merupakan kuasa yang dimiliki oleh mangsa dalam kemalangan jalanraya. Melalui suatu tuntutan yang dibuat, barulah hak-hak yang lain kemudiannya akan disahkan

93 Haslifah Hashim \& David Service, 'Modelling the Life Insurance Needs Using the Human Life Value Revision Method', Journal of Physics: Conference Series (2013): 1-10. Faktor Nilai Hidup Manusia (HLVF) merupakan kaedah pengiraan saintifik bagi mengukur kadar kewangan sebenar yang diperlukan oleh insurans hayat manusia.

94 Mohamed Mat Amin \& ORS v. Mohd Rabu Ihsan [2002] 5 CLJ

95 Harga Emas Trading, 'Harga Emas Hari Ini', laman sesawang Harga Emas Trading Sdn Bhd, http://www.hargaemas.com.my/, dicapai pada 25 Jun 2018.

96 Azman Kasri \& Anor v. Md. Isa Endut \& Government of Malaysia [1988] 1 CLJ

97 Haslifah Hashim \& David Service, 'Modelling the Life Insurance Needs Using the Human Life Value Revision Method', Journal of Physics: Conference Series (2013): 1-10. 
oleh Mahkamah. Malahan, seandainya tiada apa-apa tuntutan dikemukakan oleh mangsa atau wakilnya di Mahkamah dalam tempoh tertentu, maka mahkamah boleh menganggap pihak mangsa tidak berminat untuk membuat apa-apa tuntutan. Satu tuntutan sivil boleh dibuat di Mahkamah Majistret atau Sesyen mengikut jumlah tuntutan dan bidangkuasa masing-masing. Tuntutan pula boleh diklasifikasikan kepada tuntutan ganti rugi am dan khas.

Berbeza dengan penetapan ganti rugi mengikut kaedah diat Islam, kadarnya telah ditetapkan secara tetap berdasarkan sumber hadis. Penetapan semasa ke atas kuantum ganti rugi boleh dibuat dengan nisbah nilaian emas. Lantaran itu, semakan berkala tidak perlu dilakukan kerana nilai diat ini sentiasa diperbaharui secara automatik mengikut turun naik nilai emas. ${ }^{98}$ Walau bagaimanapun, kaedah diat Islam tidak pula menetapkan adanya ganti rugi bagi elemen-elemen kehilangan pendapatan, kehilangan kebolehan untuk meraih pendapatan dan ganti rugi atas kesengsaraan dan penderitaan yang dialami oleh mangsa. Sebaliknya, tuntutan bukan fizikal ini boleh dituntut atas kapasiti ganti rugi jaminan (al-daman).

Penyelesaian bagi kes-kes kemalangan jalan raya juga termasuk dalam maqāșid yang telah ditetapkan Syariah. Pemeliharaan nyawa dan tuntutan hak berkaitan kecederaan peribadi terangkum dalam tujuan kedua daripada lima maqāșid utama. Hal ini memberi isyarat bahawa Islam turut meraikan perundangan dan sistem pemberian pampasan yang komprehensif sebagai satu bentuk mașālih al-mursalah. Dalam aspek lain, rentetan yang timbul daripada suatu kemalangan jalan raya adalah hak-hak dan liabiliti yang terkait dengan mangsa dan pihak yang cuai. Antara hak mangsa yang timbul akibat kecederaan dalam kemalangan ialah hak untuk membuat tuntutan, hak untuk didengar dan hak untuk mendapatkan pampasan atas kecederaan dan kehilangan yang dialami. Bagi memastikan hak dan liabiliti ini berada pada posisi yang betul, pembuktian ke atas fakta dan keterangan perlu dikemukakan terlebih dahulu.

Walau bagaimanapun, pengkaji mendapati bahawa mekanisme insurans dan takaful menepati tafsiran 'aqilah pada zaman kini. Konsep asas insurans dan takaful, iaitu sebagai sokongan dan jaminan kepada satu risiko dan kerugian yang timbul diserlahkan menerusi peruntukan khusus yang wujud dalam sistem pengurusannya. Namun demikian, dana tersebut hanya terhad ke atas pemegang polisinya sahaja. Hal ini bermaksud, pihak mangsa yang tidak dilindungi oleh polisi insurans dengan sekurang-kurangnya polisi perlindungan pihak ketiga tidak akan dipampas melalui insurans ini. Pilihan terakhir yang mereka ada adalah tuntutan kepada Biro Insurans Motor (MIB). MIB merupakan sebuah tabung ihsan juga mempunyai hadnya. Oleh sebab

98 Sunan al-Nasā’’i al-Sughrā, Kitab al-Qasamah, hadis no. 4797. 
ia merupakan sebuah tabung kebajikan, maka kadar pampasan yang boleh dituntut adalah sangat minima serta tidak mencakupi mangsa yang tidak diketahui pesalahnya atau mangsa langgar lari.

Lantaran itu, bagi memastikan kemampanan, pendapatan yang diterima oleh syarikat insurans mestilah mencukupi untuk membayar tuntutan dan perbelanjaan lain dengan margin keuntungan yang munasabah. Di bawah persekitaran tarif penuh apabila kadar premium ditetapkan, kos dan perbelanjaan tuntutan mestilah dikendalikan dengan berhemat bagi memastikan dana yang mencukupi untuk penanggung insurans membayar tuntutan. Bagi insurans am (termasuk motor), BNM memperkenalkan dasar kawalan kos operasi untuk menetapkan had komisyen dan perbelanjaan lain. Untuk membendung kos tuntutan, pelbagai inisiatif telah diperkenalkan untuk mengatasi ketirisan akibat penipuan dan juga membetulkan ketidakcekapan.

Berlainan dengan sistem diat, pesalah yang tidak memiliki 'aqilah akan disokong melalui pendanaan Baitulmal. Baitulmal menjadi badan kedua setelah 'aqilah yang pasti akan dapat menampung kadar pampasan yang dituntut. Sudah tentu dengan adanya perkongsian bayaran pampasan daripada pesalah sendiri. Walau bagaimanapun, sama ada sistem insurans, takaful, baitulmal atau dana awam lain yang menjadi mekanisme pembayaran, asas yang menjadi harapan penyelidikan ini ialah penggunaan kuantum diat sebagai dasar kepada anggaran jumlah kerugian; sama ada kecederaan fizikal atau kematian yang dibuat kepada mangsa dan orang yang terlibat. Oleh sebab itu, bagi mewujudkan sistem pampasan yang komprehensif dan segera, pengharmonian antara sistem pampasan sivil dan prinsip diat perlu direalisasikan.

\section{RUJUKAN}

'Abd al-Qādir 'Awdah, al-Tashri' al-Jinā' ’̀ al-Islāmi Muqāranan bi al-Qānūn al-Wạ̣ 'ī, vol. 1 (Bayrūt: Dār al-Kutub al-Azali, 2008).

Abdul Basir Mohamad, 'Tanggungjawab Pemunya dan Pemilik Haiwan dalam Undang-Undang Tort Islam,' Jurnal Islamiyyat, 20 (1999): 3-19.

Ahmad Muhammad Husni, 'Kedudukan Insurans Sebagai Pengganti Aqilah Bagi Pembayaran Diat dalam Kes Kemalangan Jalan Raya Menurut Undang-undang Islam', International Journal of West Asian Studies, 4/1 (2012): 1-12.

Ahmad Muhammad Husni, 'The Status of Insurance as an Alternative to Aqilah for Diat Payments Pertaining to Road Accidents', International Business Management, 7/1 (2013): 8-13.

al-Bayḥaqī, Sunan al-Bayḥaq̄̄ al-Ṣughra, vol. 4 (Bayrūt: Dār al-Kutub al'Ilmiyyah, 2008). 
Al-Mawardī, 'Alī Ibn Muhammad, al-Hāwwì al-Kabīr fì Fiqh Madhhāb alImām al-Shāfi 'ĩ: Wa huwa Sharh Mukhtassar al-Muzanī (Bayrūt: Dār al-Kutub al-'Ilmiyyah, 1999).

Al-Mawardī, Abī al-Ḥassan 'Al̄̄ Ibn Muḥammad, al-Aḥkām as-Sulțāniyyah wa al-Wilāyah al-Dīniyyah (Kuwait: Maktabah Dār Ibn Qutaybah, 1989).

Association of Malaysian Loss Adjuster, 'About AMLA', laman sesawang AMLA, http://www.amla1981.org/?page_id=1777, dicapai pada 23 Julai 2017.

Association of Malaysian Loss Adjuster, 'Member Companies', laman sesawang AMLA, http://www.amla1981.org/?page_id=3045, dicapai pada 23 Julai 2017.

Association of Malaysian Loss Adjuster, 'Role of Adjuster', laman sesawang AMLA, http://www.amla1981.org/?page_id=3041, dicapai pada 23 Julai 2017.

Azman Mohd Noor \& Mohamad Asmadi Abdullah, 'Takaful (Islamic Insurance) Benefit: Ownership and Distribution Issues in Malaysia', Journal of Islamic Economics, Banking and Finance, 5/3 (t.t.): 35-48.

Bank Negara Malaysia, 'Kestabilan Kewangan: Penyeliaan', laman sesawang Bank Negara Malaysia, http://www.bnm.gov.my/index. php?ch=fs\&pg=fs_spv\&ac=395\&lang=bm, dicapai pada 21 Julai 2017.

David Goguen, J.D., 'Determining Fault in a Personal Injury Case,' laman sesawang AllLaw.com, http://www.alllaw.com/articles/nolo/personalinjury/determining-fault.html, dicapai pada 19 Oktober 2016.

Harga Emas Trading, 'Harga Emas Hari Ini', laman sesawang Harga Emas Trading Sdn Bhd, http://www.hargaemas.com.my/, dicapai pada 25 Jun 2018.

Haslifah Hashim \& David Service, 'Modelling the Life Insurance Needs Using the Human Life Value Revision Method', Journal of Physics: Conference Series (2013): 1-10.

Jalāl al-Dīn Abd Raḥmān al-Suyūṭ̂̄, al-Ashbah wa al-Nazā ’ir fì Qawā 'id wa Furū' Fiqh al-Shāfi 'ī, (Bayrūt: Dār al-Kutub al-'Ilmiyyah, 1983).

Joni Tamkin Borhan \& Che Zarrina Sa'ari, 'The Principle of al-Takaful (Collective Responsibility) in Islam and Its Practice in the Operations of Syarikat Takaful Malaysia Berhad', Jurnal Usuluddin, 17 (2003), 33-56.

Kamal Halili Hassan, 'Akta Umur Persaraan Minimum 2012 (Akta 753); Ulasan Perundangan', Jurnal KANUN, 2 (2014): 297-300.

Al-Kasānī, 'Ala al-Dīn, Baḍ̄ 'i ' al-Șanā 'i ' fì Tartīb al-Sharā'i', vol. 7 (Bayrūt: Dār al-Kitāb al-'Arabī, 1982). 
Khalid Saifullah Al Rahmani, 'Fiqh of Traffic-Walking and Driving', laman Sesawang Islamic Foundation of Toronto, http://www.islamicfoundation. ca/general.aspx/answers/fiqh_of_traffic_-_walking_and_driving, dicapai pada 19 Oktober 2016.

Life Insurans Association Malaysia, 'About LIAM, Vission \& Mission', laman sesawang LIAM, https:/www.liam.org.my/index.php/home/ liam-missionavision, dicapai pada 23 Julai 2017.

Mohd Saad Abdul Rahman, 'Kemalangan Jalan Raya Tanggungjawab Siapa?' laman sesawang IKIM, http://www.ikim.gov.my/index.php/en/ artikel/7360-kemalangan-jalan-raya-tanggungjawab-siapa, dicapai 19 Oktober 2016.

Mohd. Sadad Mahmud \& Radiah Abd. Kader, 'Perkembangan Takaful di Malaysia: Satu Kajian Undang-Undang Kewangan Islam,' KANUN: Jurnal Undang-Undang Malaysia, 24/2 (2012): 240-261.

Muhammad Ahmad Saraj, Daman al-Udwan fi al-Fiqh al-Islami Dirasah Fihiyyah Muqaranah bi Ahkam al-Masuliyyah al-Taqsiriyyah fi alQanun (al-Qahirah: Dar al-Thaqafah li al-Nasyr wa al-Tawzi, 1990).

Muhammad Yamin Ismail, 'Perbandingan Kontrak Insurans Islam dan Konvensional', Jurnal Penyelidikan Islam, 19 (2006): 55-70.

Nor Azila Zainal Abidin, Kerjaya dalam Bidang Insuran (Batu Caves: PTS Publishing House, 2008), 32.

Persatuan Insurans Am Malaysia, 'About Us', laman sesawang PIAM, http:// www.piam.org.my/about-us/, dicapai pada 23 Julai 2017.

Persatuan Insurans Am Malaysia, 'Company Member', laman sesawang PIAM, http://www.piam.org.my/about-us/member-companies/, dicapai pada 23 Julai 2017.

Persatuan Insurans Am Malaysia, Laporan Tahunan (Kuala Lumpur: PIAM, 2013).

Portal Rasmi Kementerian Kewangan Malaysia, 'Laporan Ekonomi 2016/2017', laman sesawang Kementerian Kewangan Malaysia, http:// www.treasury.gov.my/pdf/ekonomi/le/1617/bab5.pdf, dicapai pada 22 Julai 2017.

Salleh Buang, Undang-undang Kecuaian di Malaysia, terj. Asiah Mohd Yusof, (Kuala Lumpur: Dewan Bahasa dan Pustaka, 1999).

Siti Zubaidah Ismail, 'Kecuaian dan Penentuan Liabiliti dalam Kes Kemalangan Jalan Raya Menurut Undang-undang Islam,' Malaysian Journal of Syariah and Law, 1 (2009): 82-95. 
The Malaysian Insurance and Takaful Brokers Association, 'About MITBA', laman sesawang MITBA, http://www.mitba.org.my/About-MITBA/ Our-Vision,-Mission-Objectives, dicapai pada 23 Julai 2017.

The Malaysian Insurance and Takaful Brokers Association, 'History of Mitba', laman sesawang MITBA, http://www.mitba.org.my/About-MITBA/ History-of-MITBA, dicapai pada 23 Julai 2017.

Wahbah al-Zuhaylī, Nazariyyah al-Daman wa Ahkām al-Mas'ūliyyah alMadaniyyah wa al-Jinā'iyyah fì al-Fiqh al-Islāmī Dirāsah Muqāranah (Dimashq: Dār al-Fikr, 1998).

Yuzvovich, Larisa, Elena Knyazeva, Elena Razumovskaya \& Vadim Katochikov, 'Vehicle Insurance Financial Mechanism,' Review of European Studies, 7/3 (2015): 99-12.

\section{Statut}

Akta Insurans 1996 (Akta 553)

Akta Takaful 1984 (Akta 312)

Akta Perkhidmatan Kewangan 2013 (Akta 758)

Akta Perkhidmatan Kewangan Islam 2013 (Akta 759)

Akta Pengangkutan Jalan 1987 (Akta 333)

\section{Temu bual}

Abdullah Ahmad (Peguam Berdaftar Berpengalaman Mengendali Kes Tuntutan Kemalangan Jalan Raya), dalam temu bual beliau dengan penulis, pada 23 Oktober 2016.

Afiza Abdullah (Jabatan Pembangunan Insurans, Bank Negara Malaysia), dalam temu bual beliau dengan penulis, pada 3 Mei 2018).

Muhammad Zaim Azfar Jalaludin (Peguam Berdaftar Berpengalaman Mengendali Kes Tuntutan Kemalangan Jalan Raya), dalam temu bual beliau dengan penulis, pada 3 Ogos 2016.

Roslan Ramlee (Pegawai Penyiasat Trafik, IPD Shah Alam), dalam temu bual beliau dengan penulis, pada 4 April 2017. 